\title{
Blood Group Change in Pediatric Leukemia: A Rare Phenomena
}

\author{
Venkatraman Radhakrishnan ${ }^{1} \cdot$ Sourav Mishra ${ }^{1}$. \\ Narmada Bhaskar ${ }^{2}$. Tenali Sagar ${ }^{1}$
}

Received: 7 October 2015 / Accepted: 28 December 2015 /Published online: 25 January 2016

(C) Dr. K C Chaudhuri Foundation 2016

To the Editor: We present two leukemia patients whose blood group changed during the course of their treatment. The first case was a 17-y-old boy with acute myeloid leukemia (AML) whose blood group at presentation was $\mathrm{O}$ Rhesus positive $(\mathrm{O}$ $\mathrm{Rh}+\mathrm{ve})$. After 2 cycles of induction chemotherapy his disease was in remission, however, his blood group changed to $\mathrm{A}$ $\mathrm{Rh}+\mathrm{ve}$. He subsequently received $\mathrm{A} \mathrm{Rh}+$ ve blood products without any transfusion reactions. The patient continues to be in remission and his blood group still remains $\mathrm{A} \mathrm{Rh}+\mathrm{ve}$. The second case was an 11-y-old boy with acute lymphoblastic leukemia (ALL) whose blood group at presentation in March 2011was B Rh negative (B Rh-ve). However, his blood group changed to B Rh + ve when he relapsed in May 2015, only to revert back a month later to B Rh-ve after he attained remission with chemotherapy. The patient's blood group changed back to B Rh + ve after 2 mo in August 2015 when his disease relapsed again. In both the cases the patients' blood groups were determined by their disease remission status. The ABO blood group genes encode glycosyl transferase enzymes which modify the carbohydrate content of the blood group antigens on the red blood cell (RBC) surface and determine the blood group of an individual [1]. The mechanism underlying blood group change in leukemia is not clear as was seen in our patients. It has been proposed that in some leukemic

Venkatraman Radhakrishnan

venkymd@gmail.com

1 Department of Medical Oncology, Cancer Institute (WIA), Adyar, Chennai 600020, India

2 Department of Transfusion Medicine, Cancer Institute, Adyar, Chennai, India patients' epigenetic modification of the promoter of $A B O$ gene in RBCs by leukemic cells leads to its suppression and consequent alteration in the blood group [2]. ABO blood group changes have been more commonly described in AML than in other hematological malignancies [3, 4]. However, most of these changes are subtle and detected on molecular studies and not detected on routine blood group typing [3]. Blood group changes have been identified prior to the diagnosis of underlying leukemia and also have shown to herald leukemia relapse [5]. These two cases are being highlighted to alert and educate the pediatricians about the rare possibility of change in blood group in leukemic patients during treatment or disease relapse.

\section{Compliance with Ethical Standards}

Conflict of Interest None.

Source of Funding None.

\section{References}

1. Franchini M, Bonfanti C. Evolutionary aspects of ABO blood group in humans. Clin Chim Acta. 2015;444:66-71.

2. Bianco-Miotto T, Hussey DJ, Day TK, O'Keefe DS, Dobrovic A. DNA methylation of the ABO promoter underlies loss of ABO allelic expression in a significant proportion of leukemic patients. PLoS ONE. 2009;4:e4788.

3. Bianco T, Farmer BJ, Sage RE, Dobrovic A. Loss of red cell A, B, and $\mathrm{H}$ antigens is frequent in myeloid malignancies. Blood. 2001;97: 3633-9.

4. Dobrovic A, O'Keefe D, Sage RE, Batchelder E. Imprinting and loss of ABO antigens in leukemia. Blood. 1993;82:1684-5.

5. Salmon C Blood group changes in preleukemic states. Nouv Rev Fr Hematol Blood Cells. 1976;17:211-20. 